Ichiro Nakazawa - Toshiaki Nakajima - Haruhito Harada

Tomoaki Ishigami · Satoshi Umemura · Mitsuru Emi

\title{
Human calcitonin receptor-like receptor for adrenomedullin: genomic structure, eight single-nucleotide polymorphisms, and haplotype analysis
}

Received: November 10, 2000 / Accepted: December 18, 2000

\begin{abstract}
Adrenomedullin (ADM), a peptide characterized by persistent hypotensive activity, is thought to be involved when the control mechanism of blood pressure is deranged, because its plasma concentration is upregulated in hypertensive patients. The receptor for ADM, a molecular complex consisting of calcitonin-receptor-like receptor (CRLR) and receptor-activity-modifying protein 2 (RAMP2), is activated through a unique intracellular transport mechanism. By analyzing the nucleotide sequences of bacterial artificial chromosome (BAC) clones, we have established that the gene encoding CRLR is spread over a genomic distance of 103,145 bases; it contains 15 exons interrupted by 14 introns, including 1 that spans more than 60 kilobases. Exons 1-3 constitute the $5^{\prime}$ noncoding region; exons 4 through 15 are coding elements, of which exons 8 to 14 encode seven transmembrane domains. Eight novel single-nucleotide polymorphisms (SNPs) and their allelic frequencies in the Japanese population were found by direct sequencing of 32 alleles; two SNPs were in the 5' flanking region, one in exon 2 , and the other five around intron-exon junctions. Eight haplotypes were constructed using these alleles in our Japanese population sample. The data establish a basis for investigations to detect molecular variants in the ADM receptor that might alter control of blood pressure and confer on individuals a predisposition to essential hypertension.
\end{abstract}

Key words Adrenomedullin (ADM) · Calcitonin-receptorlike receptor $($ CRLR) $\cdot$ Receptor-activity-modifying pro-

I. Nakazawa $\cdot$ T. Nakajima $\cdot$ H. Harada $\cdot$ M. Emi $(\bowtie)$

Department of Molecular Biology, Institute of Gerontology, Nippon

Medical School, 1-396 Kosugi-cho, Nakahara-ku, Kawasaki 211-8533, Japan

Tel. +81-44-733-5230; Fax +81-44-733-5192

e-mail:memi@nms.ac.jp

I. Nakazawa $\cdot$ T. Ishigami $\cdot S$. Umemura

Second Department of Internal Medicine, Yokohama City

University School of Medicine, Yokohama, Japan

T. Nakajima

Laboratory of Genetic Diagnosis, Institute of Medical Science,

University of Tokyo, Tokyo, Japan tein $2(\mathrm{RAMP} 2) \cdot$ Single-nucleotide polymorphisms (SNPs) - Haplotype $\cdot$ Vasodilation

\section{Introduction}

Adrenomedullin (ADM) is a recently identified hypotensive peptide, discovered by monitoring the elevated activity of platelet cyclic adenesine monophosphate (cAMP) in a human pheochromcytoma (Kitamura et al. 1993). ADM is characterized by its strong and persistent hypotensive activity due to dilation of the peripheral vascular bed (Ishiyama et al. 1993; Nuki et al. 1993). Plasma ADM concentrations increase in patients with hypertension, renal failure, heart failure, essential pulmonary hypertension, myocardial infarction, endotoxin shock, and many other physiological conditions (Ishimitsu et al. 1994; Jougasaki et al. 1995; Kakishita et al. 1999; Kobayashi et al. 1996; Nishio et al. 1997). ADM was first identified in adrenal medulla, but the concentration of ADM in endothelial cells is 20- to 40-fold higher than that in adrenal glands, and ADM is thought to be secreted mainly by vascular endothelial cells and smooth-muscle cells (Sugo et al. 1994a,b).

ADM receptor is a complex molecule formed by a Gprotein-coupled-receptor with seven transmembrane domains, called calcitonin-receptor-like receptor (CRLR), and a single transmembrane-domain protein called receptoractivity-modifying protein 2 (RAMP2; McLatchie et al. 1998). The mechanism for its activation is unique: CRLR is transported from endoplasmic reticulum to the cell membrane by RAMP2, where it is core-glycosylated to become a receptor for ADM.

Human CRLR mRNA was isolated from a human cerebellum cDNA library by Fluhmann et al. (1995). CRLR consists of 461 amino acids, and the gene encoding this protein lies on band q31-q32 of chromosome 2, between markers D2S2257 and D2S115 and flanked by the tissuefactor pathway inhibitor gene and the integrin alpha $\mathrm{V}$ gene.

In the work reported here we cloned the entire $C R L R$ gene and determined its genomic structure. We also identi- 
fied eight single-nucleotide polymorphisms in the gene and constructed haplotypes by direct sequencing of bacterial artificial chromosomes (BACs) and alleles in a panel of 16 normotensive Japanese individuals.

\section{Materials and methods}

Genomic cloning of the cDNA sequence

BAC screening was carried out by polymenase chain reaction (PCR), using Human Bacterial Artificial Chromosome DNA Pools Release IV (Research Genetics, Huntsville, AL, USA) (Tsukamoto et al. 1998). Human-insert DNAs on each BAC plate were amplified with the use of specific primers designed on the basis of the human CRLR cDNA sequence (Genbank accession number U17473) and ExTaq polymerase (Takara Shuzou, Kyoto, Japan). Products (5- $\mu 1$ aliquots) from each reaction were assayed on $1.0 \%$ agarose gels to decide BAC numbers. Positive BACs were incubated overnight and plasmids were extracted using the Large-Construct Kit (Qiagen, Hilden, Germany).

BAC DNA was amplified with many sets of CRLRspecific primers by LA-Taq polymerase (Takara Shuzou). All of the amplified human inserts were assayed on $1.5 \%$ agarose gels and purified using the Qiagen Gel Extraction Kit; BAC plasmids were purified separately by a phenolchloroform method. Sequences of LA-PCR products were determined using BigDye Terminator Cycle-Sequencing FS (PE Biosystems, Foster City, CA, USA) and the ABI PRISM 377-96 sequencer (Applied Biosystems, Foster City, CA, USA). The results were processed with Sequencher version 3.0 software (Hitachi Sottware, Yokohama, Japan) to construct a genomic sequence (Nakajima et al. 1999). Subsequently, primers were designed to sequence along the LA-PCR products. Direct sequencing of purified BAC plasmid was also done; the results were assembled and combined with the results of LA-PCR sequencing (Nakajima et al. 2000). To determine the transcription-start site, we performed 5' RACE (rapid amplification of cDNA ends) experiments, using cDNAs from human heart, kidney, lung, and liver, and the SMART RACE cDNA Amplification Kit (Clontech, Palo Alto, CA, USA). The CRLR gene sequence was numbered according to the results of $5^{\prime}$ RACE. To confirm the $3^{\prime}$ untranslated region (UTR) sequence and the length of exon 15, 3' RACE was done in the same way, using human heart cDNA (Kitamura et al. 1999).

Polymorphism analysis and construction of haplotypes

Blood samples from 16 Japanese volunteers were drawn into heparinized tubes, and genomic DNA was extracted by standard techniques as described previously (Emi et al.1999). All subjects gave their written informed consent to participate in the study and to supply blood samples for DNA analysis. PCR primers were designed on the basis of the $C R L R$ sequence to amplify 15 fragments, including all 15 exons and
$2 \mathrm{~kb}$ of the $5^{\prime}$ flanking region. A 2- $\mu \mathrm{l}$ sample of each product was assayed on a $1.0 \%$ agarose gel to confirm products and the rest were purified using Multiscreen FB (Millipore, Bedford, MA, USA). Direct sequencing was carried out as described previously (Seki et al. 2000) and sequences were compared by Sequencher version 3.0 to detect polymorphisms, which were confirmed by sequencing with reverse primers. Haplotypes were constructed by means of Arlequin software for population genetics data analysis (Genetics and Biometry Laboratory, Geneva, Switzerland).

\section{Results}

A human genomic segment, approximately 200-kb long, containing the entire $C R L R$ gene, was cloned as a single contig consisting of overlapping clones of BACs. Nucle-

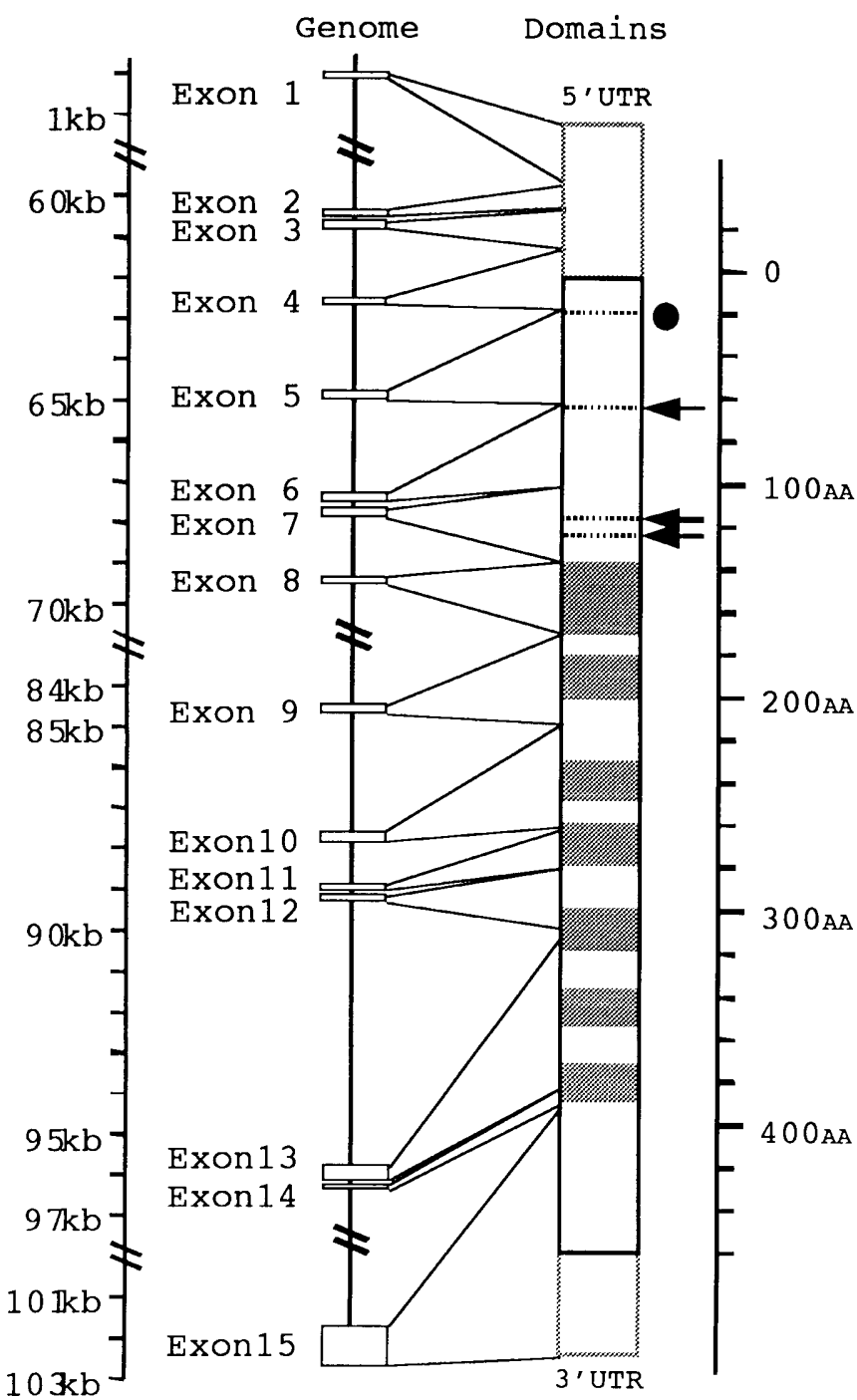

Fig. 1. Structure of the human $C R L R$ gene and relationship of exon organization and functional domains. Each gray box indicates seven transmembrane domains; arrows show potential sites for posttranslational glycosylation; closed circle indicates putative secretory signal sequence cleavage site. UTR, Untranslated region 
Table 1. $C R L R$ exons and splice junction sequence

\begin{tabular}{|c|c|c|c|c|}
\hline Exon & Position & Size & Codon & $3^{\prime}$ Splice junction/Exon $/ 5^{\prime}$ splice junction \\
\hline 1 & $1-214$ & 214 & 5' UTR & AGAACA $\cdots$ GACTGG/gtaagtgcac \\
\hline 2 & $60497-60587$ & 91 & 5' UTR & aatatttcag/GTCTTG $\cdots$ GTGCAT/gtaagtattg \\
\hline 3 & $60760-60924$ & 165 & 5' UTR & ttttctcaag/ATCGTC $\cdots$. TTCTAG/gtgagtcatt \\
\hline 4 & $62622-62708$ & 87 & 5' UTR, 1-17 & tctgttgcag/TTTATG $\cdots$ TTTATG/gtaagcataa \\
\hline 5 & $64948-65080$ & 133 & $18-62$ & aatcccttag/ATTCTT $\cdots$ CAGAAG/gtaagcatgg \\
\hline 6 & $67466-67576$ & 111 & $62-99$ & ccccactaag/GCGTTT …CATCAG/gtaaaagcag \\
\hline 7 & $67674-67786$ & 113 & $99-136$ & ttaattttaaag/AAAAAG $\cdots$ GTGAAG/gtatgtcata \\
\hline 8 & $69222-69313$ & 92 & $137-167$ & caaattacag/ACTGCA $\cdots$. TTTCAA/gtaagtaaat \\
\hline 9 & $84751-84877$ & 132 & $167-211$ & tgctttttag/GAGCCT $\cdots$ AATCCT/gtaagtaaac \\
\hline 10 & $87502-87655$ & 149 & $211-261$ & ttcctcacag/GTTAGT $\cdots$ GCTGGG/gtaagtgtta \\
\hline 11 & $88981-89041$ & 61 & $261-281$ & gttattacag/GATTTC …TGACAA/gtaagaaaat \\
\hline 12 & $89124-89190$ & 67 & $281-303$ & ttttctctag/TTGCTG $\cdots$. TTACTG/gtatgtaaca \\
\hline 13 & 95921-96139 & 219 & $304-376$ & tcgtttttag/GTGAAT $\cdots$ TTCCAG/gtatggcatt \\
\hline 14 & $96292-96333$ & 42 & $377-390$ & ttcttttacag/GGTCTT …GGAGAG/gtatgataat \\
\hline \multirow[t]{3}{*}{15} & $101851-103145$ & 1295 & 391-461, 3' UTR & tgattgatag/GTTCAA .... \\
\hline & & & & $\cdots$ AАATAAAATAGAGTCTGGAATGCT ${ }^{\mathrm{b}}$ \\
\hline & \multicolumn{3}{|c|}{ Consensus sequence ${ }^{a}$} & yyyyyynyag/GKNN $\cdots$ NMAG/gtragt \\
\hline
\end{tabular}

UTR, Untranslated region

${ }^{a}$ Consensus sequence, Breathnach and Chambon (1981); K, A/G; M, A/C; n, A/C/G/T/; r, A/G; y, C/T

${ }^{\mathrm{b}}$ Consensus polyadenylation signal in exon 15 is underlined

otide sequence analysis of LA-PCR products and BAC plasmids revealed that the human $C R L R$ gene spans 103,145 bp of genomic DNA and comprises 15 exons interrupted by 14 introns. Its exon/intron structure and the relationship of this organization to functional protein domains are shown in Fig. 1. The exons ranged in size from 42 to $219 \mathrm{bp}$, except for exon 15 (Table 1). All of the exon-intron boundaries conformed to the GT-AG rule. The introns ranged in size from 82 to $15.4 \mathrm{~kb}$, except for the giant first intron, which spanned $60.3 \mathrm{~kb}$. The translation-start codon was located in exon 4, and a stop codon was present in exon 15. A putative cleavage site for a secretory signal sequence was encoded by exon 5, and three potential post-translation glycosylation sites were encoded by exons 6 and 7. The seven transmembrane domains were encoded by exons 8 15. The results of 5' RACE experiments using human heart cDNA indicated a transcription-start site $63,657 \mathrm{bp}$ upstream of the translation-start site.

By direct sequencing, we examined $2 \mathrm{~kb}$ of the $5^{\prime}$ flanking region and $5 \mathrm{~kb}$ of exonic sequence (15 exons) including exon-intron boundaries, to detect single-nucleotide polymorphisms (SNPs) in 32 alleles from 16 Japanese individuals. Eight novel SNPs were identified in the $C R L R$ gene, two in the $5^{\prime}$ flanking region, one in exon 2 ( $5^{\prime}$ UTR), and five in exon-intron boundaries; details of these alleles and their frequencies are shown in Table 2. Haplotypes were constructed by means of Arlequin software for population genetic data analysis, using predictions from the genotypes and allele frequencies in the 16 Japanese subjects (Table 3 ).

\section{Discussion}

CRLR is a unique receptor molecule; it is an ADM receptor when united with RAMP2, and a calcitonin gene-related peptide (CGRP) receptor when united with RAMP1. ADM
Table 2. SNPs in human $C R L R$ gene in 16 Japanese samples

\begin{tabular}{lllllll}
\hline $\begin{array}{l}\text { Gene } \\
\text { region }\end{array}$ & $\begin{array}{l}\text { Nucleotide } \\
\text { position }\end{array}$ & \multicolumn{2}{l}{$\begin{array}{l}\text { Genotype } \\
(n=16)\end{array}$} & & $\begin{array}{l}\text { Allele } \\
\text { frequencies }(\%)\end{array}$ \\
\hline $5^{\prime}$ & -2041 & $\mathrm{G} / \mathrm{G}$ & $\mathrm{G} / \mathrm{A}$ & $\mathrm{A} / \mathrm{A}$ & $\mathrm{G}$ & $\mathrm{A}$ \\
& $(\mathrm{G} \rightarrow \mathrm{A})$ & 15 & 1 & 0 & $31(97)$ & $1(3)$ \\
$5^{\prime}$ & -2936 & $\mathrm{G} / \mathrm{G}$ & $\mathrm{G} / \mathrm{T}$ & $\mathrm{T} / \mathrm{T}$ & $\mathrm{G}$ & $\mathrm{T}$ \\
& $(\mathrm{G} \rightarrow \mathrm{T})$ & 15 & 1 & 0 & $31(97)$ & $1(3)$ \\
Exon 2 & 60569 & $\mathrm{~T} / \mathrm{T}$ & $\mathrm{A} / \mathrm{T}$ & $\mathrm{A} / \mathrm{A}$ & $\mathrm{T}$ & $\mathrm{A}$ \\
& $(\mathrm{T} \rightarrow \mathrm{A})$ & 10 & 6 & 0 & $26(81)$ & $6(9)$ \\
Intron 10 & 88923 & $\mathrm{C} / \mathrm{C}$ & $\mathrm{T} / \mathrm{C}$ & $\mathrm{T} / \mathrm{T}$ & $\mathrm{C}$ & $\mathrm{T}$ \\
& $(\mathrm{C} \rightarrow \mathrm{T})$ & 10 & 3 & 3 & $23(72)$ & $9(28)$ \\
Intron 11 & 89092 & $\mathrm{~A} / \mathrm{A}$ & $\mathrm{A} / \mathrm{C}$ & $\mathrm{C} / \mathrm{C}$ & $\mathrm{A}$ & $\mathrm{C}$ \\
& $(\mathrm{A} \rightarrow \mathrm{C})$ & 15 & 1 & 0 & $31(97)$ & $1(3)$ \\
Intron 13 & 96173 & $\mathrm{G} / \mathrm{G}$ & $\mathrm{A} / \mathrm{G}$ & $\mathrm{A} / \mathrm{A}$ & $\mathrm{G}$ & $\mathrm{A}$ \\
& $(\mathrm{G} \rightarrow \mathrm{A})$ & 10 & 3 & 3 & $23(72)$ & $9(28)$ \\
Intron 13 & 96197 & $\mathrm{G} / \mathrm{G}$ & $\mathrm{G} / \mathrm{A}$ & $\mathrm{A} / \mathrm{A}$ & $\mathrm{G}$ & $\mathrm{A}$ \\
& $(\mathrm{G} \rightarrow \mathrm{A})$ & 11 & 5 & 0 & $27(84)$ & $5(16)$ \\
Intron 14 & 101681 & $\mathrm{~T} / \mathrm{T}$ & $\mathrm{T} / \mathrm{G}$ & $\mathrm{G} / \mathrm{G}$ & $\mathrm{T}$ & $\mathrm{G}$ \\
& $(\mathrm{T} \rightarrow \mathrm{G})$ & 10 & 3 & 3 & $23(72)$ & $9(28)$ \\
& & & & & &
\end{tabular}

SNP, Single-nucleotide polymorphism

is a strong and long-acting hypotensive peptide, thought to affect hypertension and the physiology of other circulatory diseases. Accordingly, one would expect that the degree of expression of the CRLR gene and the receptor activity of its product would affect the occurrence or development of such conditions. In the study reported here, we investigated the human $C R L R$ gene, to determine its structure and to search for SNPs, in a panel of normotensive human volunteers. The gene consists of 15 exons interrupted by 14 introns, and spans more than $103 \mathrm{~kb}$ of genomic DNA. Its transcription start-site, as determined by $5^{\prime}$ RACE experiments, was in the same position as the $5^{\prime}$ end of an mRNA reported elsewhere as human CGRP type 1 receptor (Aiyar et al. 1996).

By direct sequencing of genomic DNAs from 16 Japanese subjects, we detected eight SNPs in the $C R L R$ gene. SNPs in coding sequences of receptor genes can 
Table 3. Predicted haplotypes and their estimated frequencies in the Japanese population

\begin{tabular}{llllllllll}
\hline & \multicolumn{7}{l}{ Nucleotide position } & \multicolumn{1}{l}{} \\
\cline { 3 - 9 } & Frequency & -2041 & -2936 & 60569 & 88923 & 89092 & 96173 & 96197 & 101681 \\
\hline 1 & 0.5000 & G & G & T & C & A & G & G & T \\
2 & 0.1875 & G & G & T & T & A & A & G & G \\
3 & 0.0938 & G & G & A & C & A & G & A & T \\
4 & 0.0625 & G & G & T & T & A & A & A & G \\
5 & 0.0625 & G & G & A & C & A & G & G & T \\
6 & 0.0313 & A & G & A & C & A & G & G & T \\
7 & 0.0313 & G & T & T & T & A & A & G & G \\
8 & 0.0313 & G & G & T & C & C & G & G & T \\
\hline
\end{tabular}

change the structure and ligand-binding activity of receptor molecules by altering amino acid sequences (Bond et al. 1998). We found no polymorphisms with amino acid replacements in the eight SNPs identified in this study. However, even SNPs in noncoding sequences can affect phenotype (Miller et al. 1999), e.g., by altering transcriptional regulation, especially when the polymorphic site lies in a promoter region, or by altering a splice site or latent splice site (Cooper et al. 1995). Moreover, SNPs are useful in themselves as polymorphic markers for locating mutations associated with specific diseases.

Adrenomedullin is thought to play an important functional role in regulating the circulatory system, and abnormal levels of this protein are implicated in the pathogenesis of hypertension. We infer that genetic variations of its receptor, CRLR, may influence susceptibility to this common disease. Additional studies, including a search for more SNPs throughout the $C R L R$ gene, and investigations of DNA from hypertensive patients, may uncover mutations that are responsible for hypertension.

Acknowledgements This work was supported in part by a special grant for Strategic Advanced Research on "Cancer" and "Genome Science" from the Ministry of Education, Science, Sports, and Culture of Japan; by a Research Grant from the Ministry of Health and Welfare of Japan; and by a Research for the Future Program Grant of The Japan Society for the Promotion of Science.

\section{References}

Aiyar N, Rand K, Elshourbagy NA, Zeng Z, Adamou JE, Bergsma DJ, Li Y (1996) A cDNA encoding the calcitonin gene-related peptide type1 receptor. J Biol Chem 271:11325-11329

Bond C, LaForge KS, Tian M, Melia D, Zhang S, Borg L, Gong J, Schluger J, Strong JA, Leal SM, Tischfield JA, Kreek MJ, Yu L (1998) Single-nucleotide polymorphism in the human mu opioid receptor gene alters beta-endorphin binding and activity: possible implications for opiate addiction. Proc Natl Acad Sci USA 95:96089613

Breathnach M, Chambon P (1981) Organization and expression of eucaryotic split genes coding for proteins. Annu Rev Biochem 50:349-383

Cooper DN, Krawczak M, Antonorakis SE (1995) The metabolic and molecular bases of inherited disease, 7th edn. McGraw-Hill, New York, USA, pp 251-291

Emi M, Keicho N, Tokunaga K, Katsumata H, Souma S, Nakata K, Taguchi K, Ohishi N, Azuma A, Kudoh S (1999) Association of diffuse panbronchiolitis with microsatellite polymorphism at the human interleukin 8 (IL-8) locus. J Hum Genet 44:169-172
Fluhmann B, Muff R, Hunziker W, Fischer JA, Born W (1995) A human orphan calcitonin receptor-like sequence. Biochem Biophys Res Commun 206:341-347

Ishimitsu T, Nishikimi T, Saito Y, Kitamura K, Eto T, Kangawa K, Matsuo H, Omae T, Matsuoka H (1994) Plasma levels of adrenomedullin, a newly identified hypotensive peptide, in patients with hypertension and renal failure. J Clin Invest 94:21582161

Ishiyama Y, Kitamura K, Ichiki Y, Nakamura S, Kida O, Kangawa K, Eto T (1993) Hemodynamic effect of a novel hypotensive peptide, human adrenomedullin, in rats. Eur J Pharmacol 241:271-273

Jougasaki M, Wei CM, McKinley LJ, Burnett JC Jr (1995) Elevation of circulating and ventricular adrenomedullin in human congestive heart failure. Circulation 92:286-289

Kakishita M, Nishikimi T, Okano Y, Satoh T, Kyotani S, Nagaya N, Fukushima K, Nakanishi N, Takishita S, Miyata A, Kangawa K, Matsuo H, Kunieda $T$ (1999) Increased plasma levels of adrenomedullin in patients with pulmonary hypertension. Clin Sci 96:33-39

Kitamura K, Kangawa K, Kawamoto M, Ichiki Y, Nakamura S, Matsuo H, Eto T (1993) Adrenomedullin: a novel hypotensive peptide isolated from human pheochromocytoma. Biochem Biophys Res Commun 192:553-560

Kitamura Y, Nakata T, Minobe K, Shimizu K, Tanaka S, Fujimori M, Yokoyama Y, Ito K, Onda M, Emi M (1999) Ret/PTC3 is the most frequent form of gene rearrangement in papillary thyroid carcinomas in Japan. J Hum Genet 44:96-102

Kobayashi K, Kitamura K, Hirayama N, Date H, Kashiwagi T, Ikushima I, Hanada Y, Nagatomo Y, Takenaga M, Ishikawa T, Imamura $\mathrm{T}$, Koiwaya $\mathrm{Y}$, Eto $\mathrm{T}$ (1996) Increased plasma adrenomedullin in acute myocardial infarction. Am Heart J 131:676680

McLatchie LM, Fraser NJ, Main MJ, Wise A, Brown J, Thompson N, Solari R, Lee MG, Foord SM (1998) RAMPs regulate the transport and ligand specificity of the calcitonin-receptor-like receptor. Nature 393:333-339

Miller JA, Thai K, Scholey JW (1999) Angiotensin II type 1 receptor gene polymorphism predicts response to losartan and angiotensin II. Kidney Int 56:2173-2180

Nakajima T, Hamakubo T, Kodama T, Inazawa J, Emi M (1999) Genomic structure and chromosomal mapping of the human sterol regulatory element binding protein (SREBP) cleavage-activating protein (SCAP) gene. J Hum Genet 44:402-407

Nakajima T, Iwaki K, Kodama T, Inazawa J, Emi M (2000) Genomic structure and chromosomal mapping of the human Siter-1 protease (S1P) gene. J Hum Genet 45:212-217

Nishio K, Akai Y, Murao Y, Doi N, Ueda S, Tabuse H, Miyamoto S, Dohi K, Minamino N, Shoji H, Kitamura K, Kangawa K, Matsuo H (1997) Increased plasma concentrations of adrenomedullin correlate with relaxation of vascular tone in patients with septic shock. Crit Care Med 25:953-957

Nuki C, Kawasaki H, Kitamura K, Takenaga M, Kangawa K, Eto T, Wada A (1993) Vasodilator effect of adrenomedullin and calcitonin gene-related peptide receptors in rat mesenteric vascular beds. Biochem Biophys Res Commun 196:245-251

Seki T, Tanaka T, Nakamura Y (2000) Genomic structure and multiple single-nucleotide polymorphisms (SNPs) of the thioprine Smethyltransferase (TPMT) gene. J Hum Genet 45:299-302 
Sugo S, Minamino N, Kangawa K, Miyamoto K, Kitamura K, Sakata J, Eto T, Matsuo H (1994a) Endothelial cells activity synthesize and secrete adrenomedullin. Biochem Biophys Res Commun 201:11601166

Sugo S, Minamino N, Shoji H, Kangawa K, Kitamura K, Eto T, Matsuo $\mathrm{H}$ (1994b) Production and secretion of adrenomedullin from vascu- lar smooth muscle cells: augmented production by tumor necrosis factor-alpha. Biochem Biophys Res Commun 203:719-726

Tsukamoto K, Ohta N, Shirai Y, Emi M (1998) A highly polymorphic CA repeat marker at the human interleukin 6 receptor (IL6R) locus. J Hum Genet 43:289-290 